\title{
Efektivitas Pelaksanaan Shalat Dhuha Dalam Peningkatan Disiplin Siswa di SMP Insan Kamil Legok Kabupaten Tangerang
}

\author{
Ika $^{1}$, Siti Maspuroh ${ }^{2}$, Pajar Milawati ${ }^{3}$ \\ ${ }^{1}$ Dosen PAI, Sekolah Tinggi Agama Islam Fatahillah Serpong Tangerang Selatan \\ Email: ikaclar@gmail.com \\ ${ }^{2}$ Fakultas Tarbiyah, Sekolah Tinggi Agama Islam Fatahillah Serpong Tangerang Selatan \\ Email: maspuroh3785@gmail.com \\ ${ }^{3}$ Fakultas Tarbiyah, Sekolah Tinggi Agama Islam Fatahillah Serpong Tangerang Selatan \\ Email: fajarmilawati24@gmail.com
}

\begin{abstract}
The research objective was to determine how the Duha prayer activities were implemented and how the effectiveness of the Duha prayer activities at Insan Kamil Legok Middle School, Legok District, Tangerang Regency. This research uses qualitative research. To obtain data or information relevant to the problem being sought. Researchers used several methods, namely the method of observation, interviews, and documentation. By using these three methods, the researcher found data about the dhuha prayer activities at Insan Kamil Legok Middle School, Legok District, Tangerang Regency. The dhuha prayer activity is an activity that must be followed by all students. For the implementation of the Dhuha prayer is carried out every day and five times a week, the series of Duha prayer activities are (a) the Dhuha prayer which is held at 10:00 before recess (b) the Duha prayer which is performed twice greetings (c) wiridan and the recitation of the Duha prayer collectively led by the supervisor of the dhuha prayer activities and sometimes led directly by students. The model for evaluating the effectiveness of the implementation of dhuha prayer activities is based on the evaluation criteria of the preordinate approach with the evaluation model, namely Context Evaluation, Input Evaluation, Process Evaluation and Product Evaluation. From the findings and the CIPP evaluation model used, it can be seen that the effectiveness of the implementation of the Duha prayer at Insan Kamil Legok Middle School, Legok District, Tangerang Regency, in terms of context, is ineffective due to the lack of cooperation among teachers in an effort to improve student discipline to perform dhuha prayers. In terms of input it has been effective, because the educational background of the supervisor of the Duha prayer activity is a religious scholar. So, this is in accordance with the dhuha prayer activities. seen from the point of view of the process has not been effective, because of the lack of efforts of the supervisor of the Duha prayer activities in increasing student awareness to perform Duha prayer. Meanwhile, in terms of products or results, it is not yet effective, because the aim of enabling students to pray Duha through the Duha prayer activities has not been fully successful as expected.
\end{abstract}

Keywords : Implementation, Dhuha Prayer, and Discipline.

\begin{abstract}
Abstrak. Tujuan penelitian untuk mengetahui bagimanakah pelaksanaan kegiatan shalat dhuha dan bagaimanakah efektivitas pelaksanaan kegiatan shalat dhuha di SMP Insan Kamil Legok Kecamatan Legok Kabupaten Tangerang. Penelitian ini menggunakan jenis penelitian kualitatif. Untuk memperoleh data atau informasi-informasi yang relevan dengan masalah yang dicari. Peneliti menggunakan beberapa metode yaitu metode observasi, wawancara, dan dokumentasi. Dengan menggunakan ketiga metode ini, peneliti menemukan data mengenai kegiatan shalat dhuha di SMP Insan Kamil Legok Kecamatan Legok Kabupaten Tangerang. Kegiatan shalat dhuha merupakan kegiatan yang harus diikuti oleh seluruh siswa. Untuk pelaksanaan shalat dhuha dilaksanakan setiap hari dan lima kali dalam seminggu, rangkaian pelaksanaan kegiatan shalat dhuha yaitu (a) shalat dhuha yang dilaksanakan pada jam 10.00 sebelum jam istirahat (b) shalat dhuha yang dilakukan dua kali salam (c) wiridan dan pembacaan doa dhuha secara bersama-sama yang dipimpin oleh pembina kegiatan shalat dhuha dan terkadang dipimpin langsung oleh siswa. Adapun model penilaian efektivitas terhadap pelaksanaan kegiatan shalat dhuha siswa berdasarkan pada kriteria evaluasi pendekatan pre-ordinate
\end{abstract}


dengan model evaluasi yaitu Evaluasi Konteks (Context Evaluation), Evaluasi Masukan (Input Evaluation), Evaluasi Proses (Process Evaluation) dan Evaluasi Produk (Product Evaluation). Dari hasil temuan dan model evaluasi CIPP yang digunakan dapat diketahui bahwa efektivitas pelaksanaan kegiatan shalat dhuha di SMP Insan Kamil Legok Kecamatan Legok Kabupaten Tangerang dari segi konteks tidak efektif disebabkan kurangnya kerjasama sesama guru-guru dalam upaya meningkatkan kedisiplinan siswa untuk melaksanakan shalat dhuha. Dalam segi masukan sudah efektif, karena latar belakang pendidikan pembina kegiatan shalat dhuha merupakan sarjana agama. Jadi, ini sesuai dengan kegiatan shalat dhuha . dilihat dari segi proses belum efektif, karena kurangnya upaya pembina kegiatan shalat dhuha dalam meningkatkan kesadaran siswa untuk melaksanakan shalat dhuha. Sedangkan dari segi produk atau hasil belum efektif, karena tujuan untuk membisakan siswa melakukan shalat dhuha melalui kegiatan shalat dhuha belum sepenuhnya berhasil sesuai dengan yang diharapkan.

Kata Kunci : Pelaksanaan, Shalat Dhuha, dan Disiplin.

\section{PENDAHULUAN}

Memasuki era globalisasi saat ini, membuat manusia sibuk dengan berbagai kebutuhan hidup yang semakin meningkat. Hal ini mengakibatkan semakin tajamnya persaingan. Tetapi, yang perlu diingat bahwa keterampilan technology itu mesti diimbangi keimanan dan ketakwaan kepada Allah SWT. Tanpa berpegang teguh pada agama dan taqwa kepada Allah SWT, pemahaman, jabatan, serta kedudukan akan membahayakan keselamatan umat manusia. Pendidikan berusaha mengembangkan potensi individu agar mampu berdiri sendiri. Untuk itu individu perlu diberi berbagai kemampuan dalam pengembangan berbagai hal, seperti: konsep, prinsip, kreativitas, tanggung jawab, dan keterampilan. Dengan kata lain perlu mengalami perkembangan dalam aspek kognitif, afektif, dan psikomotor. Demikian lingkungan sesamanya, objek sosial ini akan berpengaruh terhadap perkembangan individu. Melalui pendidikan dapat dikembangkan suatu keadaan yang seimbang antara perkembangan aspek individual dan aspek sosial. Aspek lain yang dikembangkan adalah kehidupan susila. Hanya manusialah yang dapat menghayati norma-norma dan nilai-nilai dalam kehidupannya, sehingga manusia dapat menetapkan tingkah laku mana tang baik dan tingkah laku mana yang tidak baik dan tidak bersifat susila. Aspek lain adalah kehidupan relegius dalam hubungannya dengan Tuhan Yang Maha Esa dapat menghayati dan mengamalkan ajarannya sesuai dengan agamanya. Semua itu dapat terwujud melalui pendidikan (Nanang, 2004).

Urgensi pendidikan agama terhadap pembentukan pribadi perlu diwujudkan. Pribadi-pribadi yang baik akan membentuk masyarakat yang baik. Demikian pula masyarakat yang baik, damai, sejahtera akan membentuk Negara yang kuat dan sejahtera. Oleh karena itu, pendidikan agama sebagai salah satu sarana mendidik pribadi di sekolah, perlu diatur pelaksanaannya secara efektif (Windy, 2019). Pendidikan agama biasanya diartikan pendidikan yang materi bahasannya berkaitan dengan keimanan, ketakwaan, akhlak dan ibadah kepada Tuhan. Dengan demikian pendidikan agama berkaitan dengan pembinaan sikap mental spiritual yang selanjutnya dapat mendasari tingkah laku manusia dalam berbagai bidang kehidupan. Pendidikan agama tidak terlepas dari upaya menanamkan nilai-nilai serta unsur agama pada jiwa seseorang (Sa'id, 2005).

Pendidikan shalat sangat besar manfaatnya bagi umat manusia, dengan shalat manusia akan selalu ingat Allah SWT sehingga akan terhindar dari perbuatan keji dan mungkar, serta shalat dapat membuka hati pada kebenaran dan masih banyak lagi manfaatnya. Akan tetapi pada zaman sekarang ini banyak orang yang masih melalaikan shalat. Mereka masih tetap melakukan segala perbuatan keji dan munkar. Mereka tidak sadar bahwa dengan meninggalkan shalat fardhu secara sengaja, maka ia telah ingkar dengan nyata- nyata.

Shalat merupakan salah satu rukun Islam yang bersifat wajib dan sunat. Shalat merupakan rukun islam yang paling utama setelah dua kalimat syahadat. Melaksanakan shalat wajib atas setiap orang muslim laki-laki dan perempuan dalam kondisi apapun, baik dalam keadaan sehat ataupun sakit. Shalat merupakan suatu ibadah yang terdiri dari perkataan maupun perbuatan, yang di mulai dengan takbir, dan di akhiri dengan salam. 
Shalat merupakan jalinan (hubungan) yang kuat antara langit dan bumi, antara Allah dan hamba-nya. Shalat dalam islam memiliki kedudukan yang tinggi yaitu sebagai rukun dan tiang agama. Shalat menempati rukun kedua setelah membaca kedua syahadat, serta menjadi lambang hubungan yang kokoh antara Allah dan hamba-nya. Pada saat melaksanakan shalat, hamba-hamba Allah berada dalam keadaan bersih dan suci. Mereka bermunajat, berdoa sembari mengharap kepada Allah Subhanahu wa Ta'ala agar diberikan keteguhan (Istiqamah) dalam beragama dan senantiasa memohon petunjuk-Nnya (Syekh Hilmi, 2010).

Di dalam shalat, seorang muslim mewujudkan perintah Allah pada setiap anggota badannya, hal itu agar dirinya terbiasa taat kepada Allah Subhanahu wa Ta'ala, dan melaksanakan perintahnya dalam segala aspek kehidupannya, pada prilaku pergauylan, makanan, pakaian, dan seterusnya sehingga ia terbentuk menjadi pribadi yang taat kepada Tuhannya didalam shalat maupun diluar shalat. Shalat mencegah dari perbuatan munkar dan merupakan sebab dihapuskannya kesalahan.

Shalat Sunnah memberikan banyak keuntungan, setelah shalat wajib tentunya, bagi orang yang melaksanakannya. Salah satu keuntungan itu adalah diberikan keteguhan (istqamah) yang dapat terwujud dalam tingkat kedisiplinan seorang hamba dalam melaksanakan ibadah. "Salah satu fungsi dari ibadah shalat Sunnah yaitu untuk menyempurnakan kekurangan yang ada pada shalat wajib" (Khalillurrahman, 2015).

Shalat dhuha merupakan shalat sunnah yang dikerjakan pada pagi hari, Waktu shalat dhuha dari mulai meningginya matahari satu tombak hingga sebelum matahari berada ditengah langit, sebelum tergelincir. Yang paling afdhal, melakukannya shalat itu ketika matahari sedang terik menyengat. "Barangsiapa melakukan shalat dhuha setelah matahari meninggi hingga satu tombak, tidak mengapa. Namun barangsiapa yang melakukannya ketika panas matahari terik sebelum waktu yang dilarang shalat, itu lebih afdhal". Mengenai jumlah rakaat shalat dhuha, tidak ada batasannya menurut pendapat yang shahih, karena Nabi mewasiatkan dilakukannya dua rakaat pada waktu dhuha serta menjelaskan keutamaannya (Sa'id, 2015).

Disiplin adalah sebagai proses belajar mengajar yang mengarah kepada ketertiban dan pengendalian diri, Menurut Wyckoff yang dikutip oleh Suryadi. Disiplin menurut Djamarah adalah "suatu tata tertib yang dapat mengatur tatanan kehidupan pribadi dan kelompok". Kedisiplinan mempunyai peranan penting dalam mencapai tujuan pendidikan. Berkualitas atau tidaknya belajar siswa sangat dipengaruhi oleh paktor yang paling pokok yaitu kedispilan, disamping faktor lingkungan, baik keluarga, sekolah, kedisiplinan serta bakat siswa itu sendiri. Menurut Kamus Bahasa, menyatakan bahwa disiplin adalah: 1) Tata tertib (di sekolah, di kantor, kemiliteran, dan sebagainya). 2) Ketaatan (kepatuhan) pada peraturan tata tertib. 3) Bidang studi yang memiliki objek dan sistem tertentu. Kedisiplinan adalah suatu kondisi yang tercipta dan terbentuk melalui proses dari serangkaian perilaku yang menunjukan nilai-nilai ketaatan, kepatuhan, kesetiaan, keteraturan , dan atau ketertiban.Karena sudah menyatu dengannya,maka sikap atau perbuatan yang dilakukan bukan lagi atau sama sekali tidak dirasakan sebagai beban, bahkan sebaliknya akan membebani dirinya bila mana ia tidak berbuat sebagaimana lazimnya (Ika, 2016).

Efektivitas pelaksanaan shalat dhuha merupakan langkah yang tepat. Karena ibadah shalat dhuha merupakan puncak segala kepatuhan, maksudnya adalah masih banyak orang muslim pada saat ini yang meninggalkan ibadah shalat sunnah khususnya shalat dhuha, dimana shalat dhuha sering terlupakan karena hukum pelaksanaannya yang bersifat sunnah. Maka bagi siapa yang melaksanakan karena telah menyadari pentingnya shalat dhuha tersebut, disanalah bentuk kepatuhannya terhadap Allah swt itu ada pada diri seseorang tersebut. Dengan dijalankannya shalat dhuha di sekolah secara rutin, maka siswa akan menjadi terbiasa melaksanakannya dengan disiplin. Baik siswa tersebut disaat masih bersekolah ataupun setelah lulus sekolah.

Berdasarkan observasi di SMP Insan Kamil Kecamatan Legok Kabupaten Tangerang terdapat kegiatan pelaksanaan shalat dhuha yang harus dilakukan oleh siswa kelas VII, VIII dan kelas IX. Penyelenggaraan shalat dhuha ini dilaksanakan di awal jam istirahat mereka setiap hari, dan kegiatan pelaksanaan shalat dhuha ini dilaksanakan secara berjama'ah. Kegiatan shalat dhuha ini dilakukan oleh semua siswa kelas VII, VIII, IX dan guru-guru, namun yang diutamakan untuk mengikuti shalat dhuha 
ini adalah siswa. Hal ini merupakan upaya sekolah untuk membiasakan siswa-siswanya melakukan shalat dhuha.

Namun dalam pelaksanaan shalat dhuha ini masih ada siswa yang telat datang, selain itu para siswa laki-laki terkadang masih ada yang tidak mengikuti shalat dhuha dan tidak memanfaatkan waktu yang ada dalam pelaksanaan shalat dhuha ini. Sebelum shalat dhuha di mulai para siswa laki-laki selalu menuju kekantin sekolah terlebih dahulu di bandingkan menuju ke mesjid untuk melaksanakan shalat dhuha berjama'ah ini.

Seiring berkembangnya zaman nilai-nilai kedisiplinan yang semakin memudar dan tata tertib hanya sebagai simbol saja yang tidak mempunyai kekuatan untuk mengatur kehidupan sekolah. Disinilah peran sekolah dalam hal guna menumbuh kembangkan nilai-nilai keagamaan kepada siswa dengan berbagai kegiatan shalat dhuha. Berdasarkan latar belakang tersebut, tujuan dari penulisan artikel ini adalah untuk mengetahui "Efektivitas Pelaksanaan Shalat Dhuha Dalam Peningkatan Disiplin Siswa Di SMP Insan Kamil Legok, Kecamatan Legok, Kabupaten Tangerang.

\section{METODE PENELITIAN}

Metode penelitian yang digunakan pada studi ini adalah metode kualitatif, Bagdan dan Taylor mendefinisikan "metode kualitatif" sebagai prosedur penelitian yang menghasilkan data deskriptif berupa kata-kata tertulis atau lisan dari orang-orang dan perilaku yang dapat diamati (Mamik, 2014). Penelitian deskriptif bertujuan untuk mendeskripsikan (memaparkan) peristiwa-peristiwa penting yang terjadi pada masa kini. Deskripsi peristiwa dilakukan secara sistematis dan lebih menekankan pada data faktual dari pada penyimpulan. Fenomena disajikan secara apa adanya tanpa manipulasi dan peneliti tidak mencoba menganalisis bagaimana dan mengapa fenomena tersebut bisa terjadi, oleh karena itu penelitian jenis ini tidak memerlukan adanya suatu hopotesis. Hasil penelitian deskriptif sering digunakan atau dilanjutkan dengan melakukan penelitian analitis (Nursalam, 2008).

Sumber penelitian ini adalah sumber data primer dan sumber data sekunder. Sumber data primer dalam penelitian ini diperoleh dengan melakukan observasi, wawancara yang terkait dengan efektivitas pelaksanaan shalat dhuha dalam peningkatan disiplin siswa, sedangkan sumber data sekunder berupa dokumen-dokumen yang meliputi profil sekolah, motto, visi - misi, serta berkasberkas mengenai program shalat dhuha di sekolah.

Adapun teknik yang dipergunakan dalam mengumpulkan data dari lapangan adalah metode observasi, wawancara, dan dokumentasi. Teknik analisis data menggunakan teknik analisis induktif. Metode induktif dimulai dengan pemberian berbagai kasus, fakta, contoh, atau sebab yang mencerminkan suatu konsep atau prinsip. Kemudian siswa dibimbing untuk berusaha keras mensintesiskan, menemukan, atau menyimpulkan prinsip dasar dari pelajaran tersebut. Metode ini disebut metode discovery atau socratic (Widodo, 2014). Proses induktif yaitu dari data yang terpisah namun saling berkaitan. Sedangkan aktivitas dalam menganalisis data dilakukan secara interaktif. Dimana peneliti dan obyek penelitian terlibat langsung secara terus-menerus, sehingga penelitian ini tuntas. Miles dan Huberman menyebutkan bahwa aktivitas dalam menganalisis data kualitatif dilakukan secara interaktif dan berlangsung secara terus-menerus (cyclical prosess) pada setipa tahapan penulisan, sampai tuntas dan jenuh. Aktivitas yang dilakukan dalam analisis ini adalah pengumpulan data (data collection), reduksi data (data reduction), paparan data (data display), dan kesimpulan atau verifikasi (conclusion/verification) (Prihati, 2018). Triangulasi yang digunakan ada 3 (tiga) diantaranmya adalah 1). Triangulasi sumber digunakan untuk membandingkan dan mengecek balik derajat kepercayaan suatu informasi yang diperoleh melalui waktu dan alat yang berbeda dalam penelitian. Misalnya selain menanyakan kepada siswa, peneliti juga mengkonfirmasi masalah yang sama pada guru dan kepala sekolah. 2). Triangulasi Teknik digunakan untuk menguji kredibilitas dengan cara mengecek data kepada sumber yang sama dengan teknik yang berbeda, maka peneliti melakukan diskusi untuk memastikan data mana yang dianggap benar atau mungkin semuanya benar karena dari sudut pandang yang berbeda. Misalnya data diperoleh dengan wawancara, kemudian dicek dengan observasi atau dokumentasi, teknik ini memastikan untuk mendapatkan data yang dianggap benar. 3). Triangulasi waktu digunakan untuk menguji kredibilitas dengan cara melakukan 
pengecekan dengan observasi, wawancara, atau teknik lain dalam waktu atau situasi yang berbeda. Bila hasil uji menghasilkan data yang berbeda, maka dilakukan secara berulang-ulang sehingga sampai menemukan kepastian data (Nuning, 2017).

\section{HASIL PENELITIAN DAN PEMBAHASAN}

Pelaksanaan shalat Dhuha telah diterapkan di SMP Insan Kamil Legok Kabupaten Tangerang sejak tahun 2012 yang beranjak dari sebuah usulan dan telah ditetapkan menjadi program harian. Sebagaimana hasil wawancara dengan kepala sekolah, beliau menjelaskan, "sebenarnya awal sholat Dhuha ini bukan program sekolah tapi usulan karena anak Sekolah Menengah Pertama yang lain juga melaksanakannya dengan disiplin, makanya usulan ini berawal pada tahun 2015". Hasil wawancara dengan M. Syahroji, M.A selaku kepala sekolah., beliau menjelaskan :

"shalat Dhuha ini dilaksanakan sudah lama, sejak tahun 2015 dan ini memang sudah jadi program harian di sekolah ini dan harus diikuti oleh seluruh siswa SMP Insan Kamil". M. Kusoy selaku pembina pelaksanaan shalat dhuha juga menjelaskan, "shalat Dhuha memang dilakukan sejak lama untuk membiasakan anak-anak gemar melaksanakan sholat sunnah. Sehingga yang sunnah menjadi wajib agar anak terbiasa".

Dari beberapa keterangan di atas, dapat dianalisa bahwa pelaksanaan shalat Dhuha di SMP Insan Kamil Legok Kabupaten Tangerang memang diterapkan dan menjadi program harian yang harus diikuti seluruh siswa dengan tujuan agar siswa terbiasa gemar melaksanakan shalat Dhuha. Pelaksanaan shalat Dhuha direspon baik oleh siswa, menurut siswa yang bernama Muhammad Fazar Nur, "program tersebut sangat baik, agar terbiasa sholat Dhuha dan pastinya kita akan semakin rajin dalam beribadah". Selanjutnya dari siswi yang bernama Zaky Ariansah, dia mengatakan bahwa :

"dengan diadakannya pelaksanaan shalat Dhuha setiap hari ini sangat baik untuk melatih keistiqomahan siswa dalam hal beribadah karena sudah sering dilakukan maka akan terbiasa". Siswa yang bernama Kanza Aurelia juga mengatakan bahwa "pelaksanaan shalat dhuha ini baik sekali dalam melatih kesabaran, karena tuntutan sekolah, yang mana mungkin awalnya terpaksa lama-kelamaan menjadi terbiasa".

Pelaksanaan shalat dhuha ini dianggap sangat perlu untuk menjadi salah satu pembentukan disiplin siswa. Dengan pelaksanaan shalat dhuha siwa diharapkan memiliki disiplin yang tanpa absen, tanpa pengawasan Bapak/lbu Guru, dan tanpa adanya keterpaksaan dari peraturan sekolah dapat menerapkan shalat dhuha dengan kesadaran, disiplin dan ketika sibuk beraktivitas pun dapat menyempatkan waktu untuk melaksanakn shalat dhuha. Sebagaimana yang telah dijelaskan pada Bab III, bahwa penelitian ini menggunakan teknik observasi, wawancara dan dokumentasi untuk memperoleh data yang berkaitan dengan objek penelitian yang diteliti. Oleh karena itu, dalam pembahasan ini akan dipaparkan secara rinci dan sistematis tentang objek yang diteliti dan hal itu mengacu pada fokus penelitian sebagai berikut :

\section{Pelaksanaan Kegiatan Shalat Dhuha Bersama-sama di SMP Insan Kamil Legok Kecamatan Legok Kabupaten Tangerang}

Peneliti mulai melakukan penelitian pada tanggal 30 juli sd 27 agustus 2020 di SMP Insan Kamil Legok. Berdasarkan observasi, wawancara dan pengambilan dokumentasi yang peneliti lakukan di SMP Insan Kamil Legok. Dari beberapa temuan di lapangan berkaitan dengan kegiatan shalat dhuha secara bersam-sama peneliti menemukan bahwa kegiatan shalat dhuha ini dilakukan setiap hari tepatnya pada jam 10.00 sebelum istirahat. Kegiatan shalat dhuha ini dilakukan di masjid sekolah yang berada disekitar lingkungan sekolah. Pada pelaksanaan kegiatan shalat dhuha dilakukan sebanyak dua kali salam dan dilakukan secara bersama-sama bukan secara berjama'ah. Adapun rangkaian pelaksanaan kegiatan shalat dhuha bersama-sama diantaranya : 


\section{a. Wiridan}

Wiridan merupakan kegiatan yang rutin dilakukan sesudah melaksanakan shalat dhuha. Sebagaimana yang diungkapkan oleh kepala Madrasah SMP Insan Kamil Legok, "Sebelum siswasiswi melaksanakan shalat dhuha mereka tidak ada kegiatan rutin yang dilakukan, namun setelah siswa-siswi melaksanakan shalat dhuha secara bersama-sama bukan secara berjama'ah, tetapi secara berbarengan barulah merekan membaca wirid, membaca asmaul husna, kemudian membaca do'a shalat dhuha. Terkadang membaca surat Al-Waqi'ah sebelum pelaksanaan shalat dhuha dan terkadang setelah pelaksanaan shalat dhuha tergantung siswa yang memimpinnya, guru hanya mendampingi".

Guru bidang studi pendidikan agama islam selaku Pembina kegiatan pelaksanaan shalat dhuha bersama-sama menegaskan bahwa "Siswa sesudah melaksanakan shalat dhuha membaca wiridan dan Do'a shalat dhuha terkadang membaca surah Al-Waqi'ah tergantung siswa yang memimpinnya".

Sementara itu, Guru Bimbingan Konseling menyatakan: "Sebelum jam 10.00 siswa harus ada di masjid, untuk melaksanakan shalat dhuha secara bersama-sama atau berbarengan yang dimulai jam 10.00. setelah pelaksanaan shalat dhuha selesai, barulah siswa-siswi membaca wiridan dan Do'a shalat dhuha. Tapi bagi siswa yang datang terlambat dan ketauan tidak mengikuti pelaksanaan shalat dhuha biasanya saya memberikan hukuman berdiri dilapangan sekolah. Hal ini saya lakukan untuk memberikan efek jera bagi siswa-siswa yang terlambat".

Ungkapan kepala sekolah, Pembina kegiatan pelaksanaan shalat dhuha bersama-sama dan guru bimbingan konseling tersebut sesuai dengan hasil wawancara dengan siswa yang mengikuti kegiatan pelaksanaan shalat dhuha secara bersama-sama atau berbarengan yang menyatakan: "Biasanya jam 10.00 kami mulai melaksanakan shalat dhuha, setelah kami melaksanakan shalat dhuha bersama-sama barulah kami membaca wiridan dan Do'a shalat dhuha". "Iya, kami membaca wiridan dan Do' a shalat dhuha setelah melaksanakan shalat dhuha secara bersama-sama, terkadang saya sering telat datang ke masjid ketika shalat dhuha sudah dimulai. Biasanya kalau saya telat datang saya dihukum oleh guru BK dan hukumannya disuruh berdiri dilapangan."

Dari pengamatan peneliti melihat bahwa kegiatan yang dilakukan oleh siswa sesudah melakukan shalat dhuha bersama-sama adalah wiridan dan membaca Do'a shalat dhuha berlangsung selama 15 menit. Wirid dan Do'a shalat dhuha dipimpin oleh siswa terkadang oleh guru. Sebelum membaca wirid dan Do'a shalat dhuha Qultum terlebih dahulu, dan kegiatan Qultum ini di pilih langsung oleh Pembina pelaksanaan shalat dhuha. Dan bagi siswa yang terlambat datang ke masjid di beri hukuman langsung oleh guru bimbingan konseling dan hukumannya disuruh berdiri dilapangan sekolah.

\section{b. Shalat Dhuha Bersama-Sama}

Pelaksanaan kegiatan shalat dhuha dikerjakan sebelum jam istirahat. Kegiatan shalat dhuha dikontrol langsung oleh Pembina shalat dhuha dan guru bimbingan konseling. Shalat dhuha dikerjakan secara bersama-sama artinya berbarengan bukan secara berjama'ah.

Sebagaimana yang telah diungkapkan oleh Pembina kegiatan shalat dhuha: "Kegiatan shalat dhuha ini dikerjakan secara bersama-sama dan dilakukan sebanyak 2 kali salam. Biasanya setelah pelaksanaan shalat dhuha saya selaku Pembina shalat dhuha memimpin untuk membaca wirid dan Do'a shalat dhuha dalam kegiatan shalat dhuha tersebut. Tapi terkadang saya menyuruh siswa untuk memimpin wirid dan Do'a shalat dhuha, terkadang Qultum terlebih dahulu sebelum wirid, terkadang juga membaca surah Al-Waqi'ah tergantung siswa yang memimpinnya. Dan disana saya hanya mengawasi siswa-siswa dalam pelaksanaan kegiatan tersebut bersama guru bimbingan konseling". Ungkapan Pembina shalat dhuha tersebut sesuai dengan hasil wawancara dengan siswa-siswa lain yang menyatakan: "Iya kami shalat dhuha secara bersama-sama dan dilakukan sebanyak 2 kali salam". 


\section{Efektivitas Pelaksanaan Kegiatan Shalat dhuha Dalam Peningkatan Disiplin Siswa di SMP Insan Kamil Legok Kecamatan Legok Kabupaten Tangerang.}

Pengertian efektivitas sering dikaitkan dengan pengertian efisien. Meskipun kata efektivitas sering diikuti diikuti kata efisiensi, dimana kedua kata itu berhubungan dengan produktivitas dari suatu tindakan atau hasil yang diinginkan. Namun, jika efektivitas menekankan pada hasil yang dicapai, sedangkan pengertian efisien lebih melihat pada bagaimana cara mencapai hasil yang dicapai dengan membandingkan antara input dan output.

Pendapat lebih lanjut dikemukakan Miller bahwa: "Efektivitas dimaksudkan sebagai tingkat seberapa jauh suatu sistem sosial mencapai tujuannya. Efektivitas harus dibedakan dengan efisiensi. Efisiensi mengandung pengertian perbandingan antara biaya dan hasil, sedangkan efektivitas secara langsung dihubungkan dengan pencapaian suatu tujuan".

Dengan demikian penggunaan istilah efektif adalah melakukan pekerjaan yang benar dan sesuai dengan cara yang tepat untuk mencapai suatu tujuan yang direncanakan. Sedangkan efisiensi adalah hasil dari usaha yang telah dicapai dan lebih besar dari usaha yang dilakukan. Sehingga dapat ditarik kesimpulan bahwa efektivitas dapat dikatakan sebagai keberhasilan pencapaian tujuan organisasi dari dua sudut pandang. Sudut pandang yang pertama yaitu dari segi 'hasil' maka tujuan atau akibat yang dikehendaki telah tercapai sesuai dengan yang ditentukan. Sudut pandang yang kedua dari segi 'usaha' yang telah ditempuh atau atau dilaksanakan telah tercapai sesuai dengan yang ditentukan. Efektivitas pada kesimpulannya dikatakan sebagai taraf tercapainya suatu tujuan tertentu, baik ditinjau dari segi hasil maupun segi usaha yang diukur dengan mutu, jumlah serta ketepatan waktu sesuai dengan prosedur dan ukuran-ukuran tertentu. Efektivitas berfokus pada outcome (hasil), program, atau kegiatan yang dinilai efektif, apabila output yang dihasilkan dapat memenuhi tujuan yang diharapkan (M. Alie, 2017).

Sesuai definisi tersebut, untuk dapat dikatakan efektif dan dapat memberikan manfaat, dan hasil yang diinginkan. Maka, pelaksanaan kegiatan shalat dhuha siswa di SMP Insan Kamil Legok harus memenuhi sasaran atau tujuan yang dikehendaki tercapai sesuai dengan rencana. Efektivitas menggambarkan seluruh siklus input, proses, dan output yang mengacu pada hasil guna dari pada suatu kegiatan yang menyatakan sejauh mana tujuan (kualitas, kuantitas, dan waktu) telah dicapai. Untuk mengetahui efektivitas pelaksanaan kegiatan shalat dhuha siswa, disini peneliti menggunakan pendekatan pre-ordinate, yakni peneliti membangun kriteria terstandar yang bersifat terikat berdasarkan pandangan teoritis atau tradisi tertentu yang sudah dianggap baik.

Adapun model evaluasi yang peneliti gunakan dalam penelitian ini adalah model evaluasi CIPP. CIPP merupakan sebuah model evaluasi yang menggunakan pendekatan yang berorientasi pada manajemen (management-oriented evaluation approach) atau disebut sebagai bentuk evaluasi manajemen program (evaluation in program management). Model CIPP berpijak pada pandangan bahwa tujuan terpenting dari evaluasi program bukanlah membuktikan (to prove), melainkan meningkatkan (to improve). Karenanya, model ini juga dikategorikan dalam pendekatan evaluasi yang berorientasi pada peningkatan program (improve-ment-oriented evaluation), atau bentuk evaluasi pengembangan (evaluation for development). Artinya, model CIPP diterapkan dalam rangka mendukung pengembangan organisasi tersebut mendapatkan dan menggunakan masukan secara sistematis supaya lebih mampu memenuhi kebutuhan-kebutuhan penting atau, minimal, bekerja sebaik-baiknya dengan sumber daya yang ada (Ihwan, 2011).

Model evaluasi program context, input, process, dan product (CIPP) mulai dikembangkan oleh Daniel Stufflebeam. Stufflebeam mendefinisikan evaluasi sebagai proses melukiskan, memperoleh, dan menyediakan informasi yang berguna untuk menilai alternatif-alternatif pengambilan keputusan. Melukiskan artinya menspesifikasi, mendefinisikan, dan menjelaskan untuk memfokuskan informasi yang diperlukan oleh para pengambil keputusan. Memperoleh artinya dengan memakai pengukuran dan statistic untuk mengumpulkan, mengorganisasi, dan menganalisis informasi. Menyediakan artinya mensintesiskan informasi sehingga akan melayani dengan baik kebutuhan evaluasi para pemangku kepentingan evaluasi. (Eka, 2019) Model CIPP 
terdiri dari empat jenis evaluasi, yaitu evaluasi konteks, evaluasi input, evaluasi proses dan evaluasi produk. Menurut Stufflebeam, model evaluasi CIPP bersifat linier. Artinya, evaluasi input harus didahului oleh evaluasi konteks; evaluasi proses harus didahului oleh evaluasi input, evaluasi produk harus didahului oleh evaluasi proses (Nurjannah, 2017).

a. Evaluasi Konteks (Context Evaluation)

Evaluasi konteks utamanya mengarah pada identifiksi kekuatan dan kelemahan organisasi dan pada pemberian masukan untuk memperbaiki organisasi. Tujuan pokok dari evaluasi konteks adalah menilai seluruh keadaan organisasi, mengidentifikasi kelemahannya, mendiagnosis masalah-masalah yang dihadapi organisasi, dan mencari solusi-solusinya. Evaluasi konteks juga bertujuan untuk menilai apakah tujuan-tujuan dan prioritas-prioritas yang telah ditetapkan memenuhi kebutuhan-kebutuhan pihak-pihak yang menjadi sasaran organisasi (Ihwan, 2011).

1) Melakukan kegiatan shalat dhuha bersama-sama sesuai dengan waktu yang sudah ditentukan. Kegiatan shalat dhuha bersama-sama di SMP Insan Kamil Legok merupakan kegiatan yang dilakukan setiap hari, selama 5 hari dalam seminggu tepatnya pada jam 10.00 sebelum jam istirahat. Dalam memperhitungkan jumlah jam, juga harus memperhatikan jam (waktu) yang akan dipakai. Waktu dapat berpengaruh terhadap pencapaian keberhasilan suatu kegiatan. Mengingat pentingnya peran waktu dalam suatu target yang ingin dicapai. Masalah waktu ini yang sangat diharapkan dapat diatur dengan baik, sebagaimana harapan yang semestinya. Seperti pada kegiatan pelaksanaan shalat dhuha secara bersama-sama yang dilakukan setiap hari, atau lima kali dalam seminggu. Padahal, pada dasarnya kegiatan ini sangat bagus.

2) Memotivasi siswa bahwa shalat dhuha memiliki banyak manfaat dan keutamaan. Motivasi berkaitan erat dengan segala sesuatu yang mendorong seseorang untuk bertindak melakukan sesuatu. Memotivasi siswa untuk melakukan kegiatan shalat dhuha sangat perlu dilakukan karena ini dapat mendorong dan menyadarkan siswa untuk melakukan hal tersebut. Salah satu cara yang dilakukan oleh Pembina kegiatan shalat dhuha untuk memotivasi siswa dengan cara memberikan ceramah tentang manfaat atau faedah-faedah shalat dhuha. Namun, memotivasi siswa dengan hal tersebut belum cukup. Bahwasannya dengan meningkatkan kerjasama antar sesame guru juga membantu dan mempermudah upaya dalam meningkatkan kedisiplinan siswa untuk melaksanakan shalat dhuha. Perlu ada kerjasama dengan guru-guru yang lain agar shalat dhuha ini bukan hanya dilakukan oleh siswa, namun guru juga harus bisa memberikan contoh dengan melakukan shalat dhuha bersama para siswa. Dengan demikian siswa akan termotivasi untuk melakukan shalat dhuha.

3) Mengontrol siswa dalam pelaksanaan shalat dhuha bersama-sama. Dalam mengontrol siswa Pembina merasa kesulitan, karena yang kontrol adalah seluruh siswa dari kelas satu sampai kelas tiga. Untuk dapat memperoleh hasil yang lebih baik Pembina kegiatan shalat dhuha bekerjasama dengan guru BK. Ini dilakukan supaya kegiatan shalat dhuha berjalan sesuai dengan yang diharapkan. Tetapi meskipun demikian masih ada saja siswa yang tidak mengikuti peraturan. Seperti datang terlambat, tidak membawa peralatan shalat da nada yang tidak mengikuti kegiatan shalat dhuha.

b. Evaluasi Input (Input Evaluation)

Evaluasi input teristimewa dimaksudkan untuk membantu menentukan program guna melakukan perubahann-perubahan yang dibutuhkan. Evaluasi input mencari hambatan dan potensi sumber daya yang tersedia. Tujuan utamanya ialah membantu klien mengkaji alternatifalternatif yang berkenaan dengan kebutuhan- kebutuhan organisasi dan sasaran organisasi. Dengan perkataan lain, evaluasi input berfungsi untuk membantu klien menghindari inovasiinovasi yang sia-sia dan diperkirakan akan gagal atau sekurang-kurangnya menghamburhamburkan sumber daya (Ihwan, 2011). Dari segi input/masukan, yang menjadi fokus penilaian adalah standarisasi guru yang mengontrol kegiatan shalat dhuha. Latar belakang pendidikan 
tinggi dengan program pendidikan yang sesuai dengan kegiatan shalat dhuha. Kusoy, S.Ag, selaku guru juga merupakan Pembina kegiatan shalat dhuha. Dengan latar belakang pendidikan Pembina kegiatan shalat dhuha juga sarjana pendidikan agama, ini sesuai dengan kegiatan shalat dhuha.

c. Evaluasi Proses (Process Evaluation)

Evaluasi proses pada dasarnya memeriksa pelaksanaan rencana yang telah ditetapkan. Tujuannya adalah memberikan masukan bagi pengelola atau manajer dan stafnya tentang kesesuaian antara pelaksanaan rencana dan jadwal yang sudah dibuat sebelumnya dan efisiensi penggunaan sumber daya yang ada. Apabila rencana tersebut perlu dimodifikasi atau dikembangkan, evaluasi proses memberikan petunjuknya. Masih ada tujuan-tujuan lain yang patut diperhatikan, yakni menilai secara priodik seberapa jauh penerimaan para partisipan program dan keberhasilan mereka dalam melaksanakan peran- peran mereka; dan memberikan catatan yang lengkap tentang pelaksanaan rencana dan perbandingannya dengan tujuan awalnya (Ihwan, 2011).

Dalam proses pembentukan sikap disiplin siswa, cara yang dilakukan adalah teknik external control. "Teknik external control adalah yaitu mengendalikan diri dari luar berupa bimbingan dan penyuluhan. Teknik ini dalam menumbuhkan disiplin cenderung melakukan "pengawasan" (yang kadang perlu diperketat dan kalau perlu menjatuhkan hukuman terhadap setiap pelanggaran) (Saifuddin, 2014).

Adapun yang perlu dilakukan diantaranya:

1) Siswa didorong untuk mentaati aturan dalam kegiatan shalat dhuha secara bersama-sama. Untuk mendorong siswa mentaati aturan kegiatan shalat dhuha bersama- sama, upaya yang dilakukan adalah memotivasi siswa dengan memberikan ceramah tentang manfaat dan keutamaan shalat dhuha dan memberikan sanksi atau hukuman kepada siswa yang tidak mentaati aturan. Dengan adanya sanksi atau hukuman yang diberikan dihrapkan siswa bisa disiplin mentaati peraturan dalam kegiatan shalat dhuha bersama-sama. Disiplin akan membuat siswa memiliki tanggung jawab, mampu memecahkan masalah dengan baik, cepat dan mudah.

2) Siswa harus mentaati aturan kegiatan shalat dhuha bersama-sama. Dalam kegiatan shalat dhuha bersama-sama peraturan yang harus siswa lakukan adalah siswa harus mengikuti kegiatan shalat dhuha dan siswa harus membawa peralatan shalat sendiri. Jika siswa tidak mengikuti kegiatan shalat dhuha bersama-sama dan tidak membawa peralatan shalat. Maka siswa tersebut akan diberikan hukuman oleh guru BK. Tetapi meskipun demikian, masih ada siswa yang tidak ikut melaksanakan shalat dhuha bersama-sama dan tidak membawa peralatan shalat.

3) Guru memberikan hukuman kepada siswa yang tidak mentaati aturan. Hukuman merupakan upaya yang dilakukan untuk meningkatkan kesadaran siswa agar mau melaksanakan shalat dhuha bersama-sama. Meskipun demikian hukuman tidak sepenuhnya bisa meningkatkan kesadaran siswa. Pembina kegiatan shalat dhuha juga perlu membina hubungan baik dengan para siswa. Membina hubungan baik dengan siswa adalah dengan cara memperlakukan anak didik seperti anak sendiri dimanapun dan kapanpun serta memposisikan dirinya bukan sebagai guru yang ditakuti tetapi lebih sebagai teman yang bisa diajak bertukar pendapat tanpa menghilangkan kewibawaan sebagai guru. Dengan kedekatan ini memudahkan guru dalam upaya meningkatkan kesadaran siswa untuk melaksanakan shalat dhuha bersama-sama.

\section{d. Evaluasi Produk (Product Evaluation)}

Evaluasi produk bertujuan untuk mengukur, menafsirkan, dan menilai capaian-capaian program. Lebih jelasnya, evaluasi produk bertujuan untuk menilai keberhasilan program dalam memenuhi kebutuhan-kebutuhan sasaran program. Penilaian-penilaian tentang keberhasilan program atau organisasi ini dikumpulkan dari orang-orang yang terlibat secara individual atau kolektif, dan kemudian dianalisis dari berbagai sudut pandang (Ihwan, 2011). 
Dari segi produk atau hasil, kegiatan shalat dhuha bersama-sama dikatakan efektif atau berhasil apabila tujuan atau sasaran yang dikehendaki dapat tercapai sesuai dengan rencana dan dapat memberikan dampak, hasil, atau manfaat yang diinginkan.

1) Siswa menjadi terbiasa melaksanakan shalat dhuha. Salah satu tujuan dari kegiatan shalat dhuha bersama-sama adalah siswa menjadi terbiasa melakukan ibadah sunnah seperti shalat dhuha. Agar meningkatkan ketakwaan siswa kepada Allah SWT. Namun membiasakan siswa melakukan shalat dhuha belum sepenuhnya berhasil. Karena kurangnya uapaya yang dilakukan oleh Pembina kegiatan shalat dhuha siswa dalam meningkatkan kesadaran siswa dalam kegiatan shalat dhuha bersama-sama.

2) Siswa menjadi lebih disiplin mentaati aturan yang ada disekolah. Pendisiplinan siswa melalui kegiatan shalat dhuha ini masih ada yang tidak ikut dalam melaksanakan kegiatan shalat dhuha. Dan kurangnya kerjasama antar sesama guru dalam upaya meningkatkan kedisiplinan siswa untuk melaksanakan shalat dhuha bersama-sama juga menyebabkan kegiatan ini belum sepenuhnya mencapai tujuan yang diharapkan.

\section{KESIMPULAN}

1. Pelaksanaan kegiatan shalat dhuha siswa di SMP Insan Kamil Legok. Kegiatan shalat dhuha di SMP Insan Kamil Legok dilakukan setiap hari tepatnya pada jam 10.00 sebelum jam istirahat. Kegiatan shalat dhuha ini dilakukan di masjid sekolah yang berada disekitar lingkungan sekolah. Pada pelaksanaan kegiatan shalat dhuha dilakukan sebanyak dua kali salam dan dilakukan secara bersama-sama bukan secara berjama' ah yang dipimpin langsung oleh Pembina kegiatan shalat dhuha, namun Pembina juga sering menyuruh siswa untuk memimpin pelaksanaan shalat dhuha.

2. Efektivitas Pelaksanaan Kegiatan Shalat Dhuha di SMP Insan Kamil Legok. Efektivitas pelaksanaan kegiatan shalat dhuha di SMP Insan Kamil Legok dapat dilihat dari model evaluasi CIPP yang peneliti gunakan.

a. Evaluasi Konteks (Context Evaluation) Dari segi konteks kegiatan shalat dhuha di SMP Insan Kamil Legok belum berjalan dengan efektif disebabkan karena kurangnya kerjasama antar sesama guru dalam pelaksanaan shalat dhuha.

b. Evaluasi Masukan (Input Evaluation) Dari segi input/masukan sudah efektif, karena latar belakang pendidikan Pembina kegiatan shalat dhuha merupakan sarjana agama. Jadi, ini sesuai dengan pelaksanaan kegiatan shalat dhuha.

c. Evaluasi Proses (Process Evaluation) Dalam evaluasi proses belum efektif, karena kurangnya upaya Pembina kegiatan shalat dhuha dalam meningkatkan kesadaran siswa untuk melaksanakan shalat dhuha.

d. Evaluasi Produk (Product Evaluation) Kegiatan shalat dhuha dari segi produk atau hasil belum efekif, karena tujuan untuk membiasakan siswa melakukan shalat dhuha melalui kegiatan shalat dhuha belum sepenuhnya berhasil sesuai dengan yang diharapkan.

\section{DAFTAR PUSTAKA}

Al-Khuly Syekh Hilmi, Misteri Dahsyatnya Gerakan Shalat, Jakarta: Tuhfa Media, 2010.

Al-Mahfani M Khalilurrahman, Berkah Shalat Dhuha, Jakarta: Wahyu Media, 2008.

Al-Munawar Said Agil Husin, Aktualisasi Nilai-Nilai Qur'ani Dalam Sistem Pendidikan Islam, PT.Ciputat Press, 2005.

Al-Qahthani Sa'id Bin Ali Wahf, Kumpulan Shalat Sunnah Dan Keutamaannya, Jakarta: Darul Haq, t.th. Arsip Data SMP Insan Kamil Legok Tangerang.

Ernawati Ika, Pengaruh Layanan Imformasi dan Bimbingan Pribadi Terhadap Kedisiplinan Siswa Kelas XII Cokro Aminoto Banjarnegara dalam Jurnal Bimbingan dan Konseling Vol. 01 No. 1 Tahun 2016.

Fattah Nanang, Landasan Manajemen Pendidikan, Bandung: Pt Remaja Rosdakarya, 2004. 
Humaedi M. Alie, dkk. Etnografi Bencana, Menakar Peran Para Pemimpin Lokal Dalam Pengurangan Resiko Bencana, Yogyakarta: Lkis Pelangi Aksara, 2016.

Mahmudi Ihwan, "CIPP: Suatu Model Evaluasi Program Pendidikan," dalam Jurnal At-Ta'dib. Vol. 6 No. 1 Tahun 2011.

Mamik, Metodologi Kualitatif, hal itu: t.tp. Zifatama Publisher, t.th.

Mulianto Sindu, dan dkk, Supervisi Diperkaya Perspektif Syariah, Jakarta: Elex Media Komputindo, 2006.

Nonci Nurjanah, Implementasi Program Gernas Kakao, Makassar: SahMedia, 2017.

Nurcahya Eka, Anang Multiadi, dkk. "Evaluasi Konteks dan Produk Program Badan Usaha Milik Desa," dalam Jurnal Responsive, Vol. 2 No. 3 Tahun 2019.

Nursalam, Konsep dan Penerapan Metodologi Penelitian Ilmu Keperawatan, Jakarta: Salemba Medika, 2008.

Pratiwi Nuning Indah, "Penggunaan Media Video Call Dalam Teknologi Komunikasi," dalam Jurnal IImiah Dinamika Sosial, Vol. 1, No.2, Tahun 2017.

Prihati, Implementasi Kebijakan Promosi Pariwisata Dalam Pengembangan Potensi Wisata Daerah, Surabaya: Jakad Media Publishing, 2018.

Saifuddin, Pengelolaan Pembelajaran Teoritis dan Praktis, Yogyakarta: Deepublish, 2014.

Sari Windy Dian, "Pengaruh Persepsi Faktor Rasional dan Emosional Terhadap Kepuasan Orang Tua Siswa di Sekolah Dasar Islam Terpadu Lentera Ilmu Kota Tangerang," tesis, Jakarta: PTIQ Jakarta, 2019.

Winarso Widodo. "Membangun Kemampuan Berpikir Matematika Tingkat Tinggi Melalui Pendekatan Induktif Deduktif, dan Induktif Deduktif Dalam Pembelajaran Matematika," dalam Jurnal EduMa, Vol. 3 No. 2 Tahun 2014. 